\title{
THE DERMAL BARRIER IN SYSTEMIC SCLEROSIS AND OTHER RHEUMATIC DISEASES
}

\author{
J. SHARP AND D. GOLDSBOROUGH \\ From the Departments of Rheumatism Research and Physiology, University of Manchester
}

Hyaluronidase has been shown to increase the rate of spread of intradermally injected solutions in animals (Chain and Duthie, 1939, 1940) and the whole subject of spreading factors was reviewed by Duran-Reynals (1942). Holborow and Keech (1951) studied the effects of hyaluronidase in accelerating the rate of spread of a solution of haemoglobin injected intradermally in normal human subjects and in patients with rheumatic fever and found no significant differences. In three cases of dermatomyositis, the hyaluronidase appeared to have no significant spreading effect until hypersensitivity to the enzyme developed, and the authors suggested that, in dermatomyositis, the hyaluronic component of the skin is either deficient or is unresponsive to testicular hyaluronidase.

Kellgren, Ball, and Tutton (1952) compared the rates of disappearance of the palpable blebs produced by the intradermal injection of isotonic saline with and without hyaluronidase in normal and acromegalic subjects, and found that, whereas the rates of disappearance of the saline blebs were comparable in the two groups, the hyaluronidase caused more rapid disappearance of the blebs in the normal than in the acromegalic subjects. In normal subjects, the blebs containing hyaluronidase tended to persist longer in the younger subjects who might still be growing.

The purpose of this communication is to report the results obtained on applying this test in normal subjects and in patients suffering from systemic sclerosis or other connective tissue diseases. Some of the factors concerned in the disappearance of the blebs were investigated and the possible significance of the results is discussed.

\section{Methods}

The test procedure was that described by Kellgren and others (1952). Eight sites for injection were chosen on the volar aspect of the forearm in two rows, there being
$2 \mathrm{in}$. between the rows and at least 1 in. between the sites in each row. At each of four sites $0.05 \mathrm{ml}$. physiological saline, and at the other four sites $0.05 \mathrm{ml}$. saline containing freshly added hyaluronidase, was injected intradermally. Two injections of saline and two of saline containing hyaluronidase were made at alternate sites in each row. The time taken for the intradermal blebs to become impalpable was then recorded.

The saline injections were made first, the time required to raise the four blebs varying from 30 seconds to 2 minutes. The injections of saline containing hyaluronidase were then made, each bleb being followed to disappearance before the next injection was made.

Testicular hyaluronidase (Benger's "Hyalase") waso used in a concentration of 1,500 i.u. in $100 \mathrm{ml}$. physio logical saline, almost all the experiments being performed with either Batch 11065 or Batch 14355 . The activity of the enzyme solution was tested before each experiment by intradermal injection in a normal subject, usually one of the authors, neither of whom developed hypersensitivity to the enzyme.

Skin temperatures were measured by a thermocouple applied to the skin surface.

In the experiments employing radioactive sodium, ${ }^{24} \mathrm{Na}$, the isotonic saline solutions with and without hyaluronidase were made up so that the $0.05 \mathrm{ml}$. injected contained 2 to 5 microcuries of ${ }^{24} \mathrm{Na}$. Care was taken when making the injections to avoid contamination of the skin surface.

Gamma radiation was counted using a crystal scintillation counter connected to a rate-meter, the counting rate being recorded every $15 \mathrm{sec}$., starting after removal of the syringe, until a background level had been reached. These values, less the background value, were plotted semi-logarithmically against time. The average dimension of the blebs was $7 \times 8 \mathrm{~mm}$., and the radiation was counted from the blebs and surrounding area through a circular lead-screened opening $12 \mathrm{~mm}$. in diameter, or from the centre of the blebs through an opening $4 \mathrm{~mm}$. in diameter, as indicated in the text.

The sheep cell agglutination tests were performed by the method of Ball (1950); agglutination at a titre of $1 / 32$ or higher after $18 \mathrm{hrs}$ ' incubation was recorded as a positive result. 
The full test, as described, was performed on one normal male subject aged 28 , on 4 different days. The mean durations of the hyaluronidase blebs ranged from 4.25 to 4.9 minutes (average 4.5 ), and those of the saline blebs from 55 to 67 minutes (average 62.2). This suggested that the results were reasonably reproducible.

The question of observer difference in assessing the duration of the blebs was investigated in three normal subjects and in one patient with systemic sclerosis, the duration of the blebs being assessed independently by each of the authors (Table I). Satisfactory agreement in the average time of disappearance of each type of bleb was obtained.

\section{Results}

The test was performed on nineteen normal subjects ranging in age from 17 to 68 years (average 39), of whom five were males. The results are shown in Table II. The average duration of the saline blebs was $61 \cdot 7$ minutes and of the hyaluronidase blebs 3.9 minutes. Kellgren and others (1952) obtained average durations of 36 and $2 \cdot 2$ minutes respectively for the two kinds of blebs, using this test in normal subjects whose average age was 35 years (range 16 to 69). Since the average duration of each kind of bleb in our experiments was increased in approximately the same proportion above these figures, it would appear that the difference was probably due to observer difference in assessing the time of disappearance of blebs.

Nineteen patients with systemic sclerosis of whom two were males were tested. Their ages ranged from 11 to 78 years and were distributed similarly to those of the normal subjects. The sheep cell agglutination test was positive in six of the eighteen patients tested. All of them had sclerosis of the skin with loss of mobility over underlying structures; the skin was normal at the site of testing on the forearm in only one patient, who is more fully described later. Considering the eighteen patients in whom the forearm skin was abnormal, the mean

TABLE I

INTER-OBSERVER DIFFERENCE IN HYALURONIDASE AND SALINE BLEB DISAPPEARANCE TIMES

\begin{tabular}{|c|c|c|c|c|c|c|c|c|c|c|}
\hline \multirow{4}{*}{ Subject } & \multirow{4}{*}{$\begin{array}{c}\text { Age } \\
\text { (yrs) }\end{array}$} & \multirow{4}{*}{ Sex } & \multicolumn{8}{|c|}{ Duration of Blebs (min.) } \\
\hline & & & \multicolumn{4}{|c|}{ Hyaluronidase } & \multicolumn{4}{|c|}{ Saline } \\
\hline & & & \multicolumn{2}{|c|}{ Observer 1} & \multicolumn{2}{|c|}{ Observer 2} & \multicolumn{2}{|c|}{ Observer 1} & \multicolumn{2}{|c|}{ Observer 2} \\
\hline & & & Mean & Range & Mean & Range & Mean & Range & Mean & Range \\
\hline Normal & 19 & $\mathbf{M}$ & $5 \cdot 2$ & $4 \cdot 0-5 \cdot 75$ & $4 \cdot 9$ & $4 \cdot 0-5 \cdot 25$ & 80 & 54-109 & 87 & $84-89$ \\
\hline Normal & 25 & $F$ & $4 \cdot 3$ & $3 \cdot 0-5 \cdot 0$ & $4 \cdot 1$ & $3 \cdot 0-5 \cdot 0$ & 71 & $48-79$ & $69 \cdot 5$ & $55-80$ \\
\hline Normal & 18 & $F$ & $4 \cdot 6$ & $2 \cdot 0-5 \cdot 5$ & $4 \cdot 1$ & $1 \cdot 5-5 \cdot 5$ & - & - & - & - \\
\hline Sclerotic & 22 & $\mathbf{F}$ & $9 \cdot 25$ & $7-12 \cdot 5$ & $8 \cdot 6$ & $6 \cdot 5-11 \cdot 5$ & - & - & - & - \\
\hline
\end{tabular}

TABLE II

DURATION OF SALINE BLEBS WITH AND WITHOUT HYALURONIDASE IN NORMAL SUBJECTS AND PATIENTS WITH RHEUMATIC DISEASES

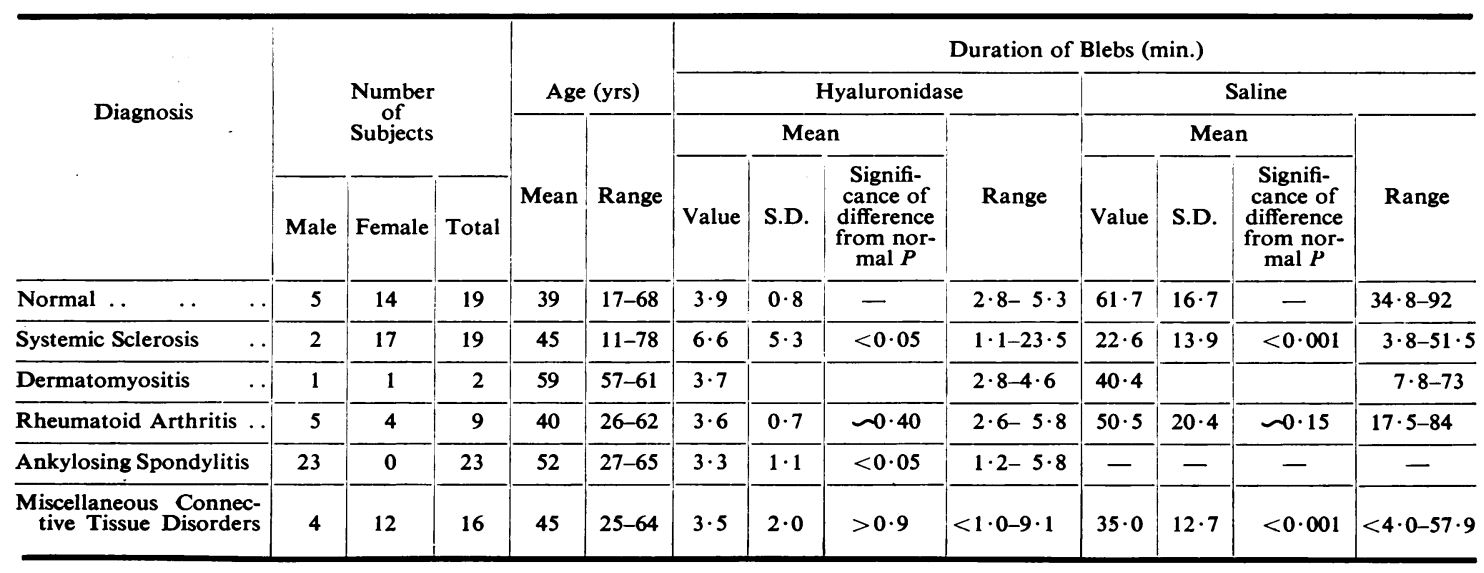


duration of the blebs containing hyaluronidase (6. 6 minutes) was longer and that of the saline blebs (22.6 minutes) was shorter than in normal subjects ( $p<0.05$ and $<0.001$ respectively) (Table II). Only three of these patients were receiving steroid or corticotrophin therapy. In two of these the duration of the hyaluronidase blebs was normal and in the third it was shorter than normal, so that a decrease in the effect of the hyaluronidase due to these agents (Seifter, Baeder, and Dervinis, 1949; Shuman and Finestone, 1950) could not explain the results.

The results of the tests in the nineteen individual patients with systemic sclerosis and in the nineteen normal subjects are indicated in Fig. 1. In normal subjects the duration of the blebs fell within the two standard deviations above and below the mean normal values for both saline and saline plus hyaluronidase.

The probability that the duration of either type of bleb would fall outside these limits by chance would be $1 / 20$, and the probability that both would do so is considerably less. Only one patient with systemic sclerosis came within this range. She had noted deterioration in her general health, stiffness in the limbs, and attacks of Raynaud's phenomenon for 2 years, and had more recently developed a sclerodermatous plaque on the forehead. Motion of many of her joints was limited and accompanied by fine "squeaking" crepitus which was also present on movement of tendons. There were possible early® sclerotic changes in the skin of the feet, but the skin 3 of the upper limbs was normal. In ten of the remaining eighteen patients with systemic sclerosis, the skin at the site of testing, though sclerotic, was of normal or increased thickness, but in the remainderwho had more advanced changes the skin was thinner than normal and more tightly bound. The results in these two groups of patients are given in $\bar{\varnothing}$ Table III (opposite). The average duration of saline blebs in patients with less advanced skin changes $\left(23^{\circ}\right.$ minutes) was almost identical with that in those with $\vec{\circ}$ advanced changes $(22 \cdot 1$ minutes), but the hyaluroni- $\overrightarrow{\vec{H}}$ dase was relatively less effective in accelerating the disappearance of blebs in those with earlier changes, the average duration of the blebs being 8.6 minutes? in this group compared with $5 \cdot 2$ minutes in those. $\vec{v}$ with advanced changes $(p<0 \cdot 20)$. The advanced $+{ }^{+}$ skin changes were of course usually encountered in $\vec{D}$ patients with longer duration of symptoms. Four-o

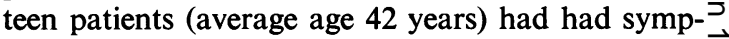
toms for 5 years or less, and five (average age 33 years) for more than 5 years (average 12.4). The mean duration of the hyaluronidase blebs in these $\frac{\mathbb{D}}{3}$ two groups was $7 \cdot 5$ and $4 \cdot 1$ minutes respectivelyo ( $p \sim 0.25$ ), and that of the saline blebs 24.9 and 16. 1 minutes $(p-0 \cdot 25)$.

The two patients listed in Table II under diagnosis of dermatomyositis were both sufferin̄go from the classical acute form of the disease.

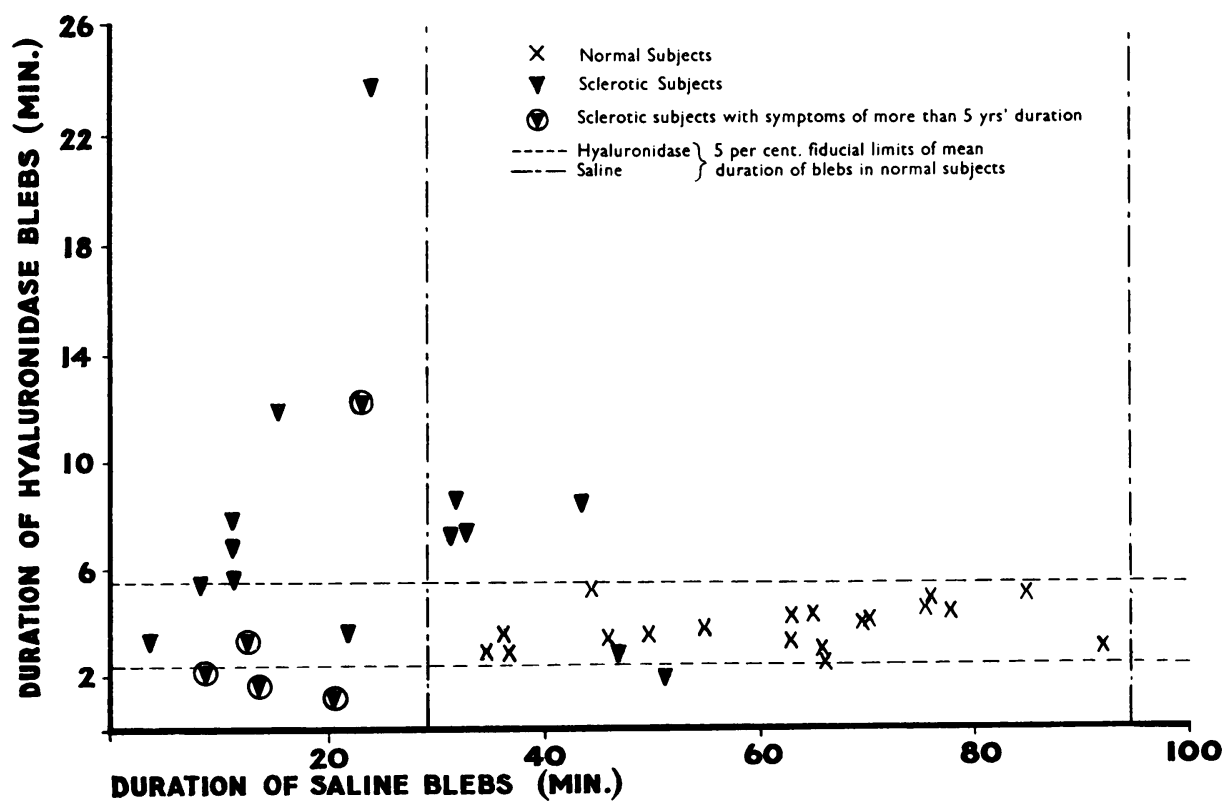

Fig. 1.-Duration of saline and hyaluronidase blebs in nineteen normal subjects and in nineteen patients with systemic sclerosis 


\begin{tabular}{|c|c|c|c|c|c|c|c|c|}
\hline \multirow{3}{*}{ State of Skin } & \multirow{2}{*}{\multicolumn{3}{|c|}{ No. of Patients }} & \multirow{3}{*}{$\begin{array}{c}\text { Age } \\
\text { Range } \\
\text { (yrs) }\end{array}$} & \multicolumn{4}{|c|}{ Duration of Blebs (min.) } \\
\hline & & & & & \multicolumn{2}{|c|}{ Saline } & \multicolumn{2}{|c|}{ Hyaluronidase } \\
\hline & Male & Female & Total & & Range & Mean & Range & Mean \\
\hline $\begin{array}{l}\text { Sclerotic but of normal or in- } \\
\text { creased thickness }\end{array}$ & 1 & 9 & 10 & $11-78$ & $3 \cdot 8-51 \cdot 5$ & 23 & $3 \cdot 3-23 \cdot 8$ & $8 \cdot 6$ \\
\hline Thin and more tightly bound & 1 & 7 & 8 & $14-62$ & $9 \cdot 4-43 \cdot 6$ & $22 \cdot 1$ & $1 \cdot 1-8 \cdot 5$ & $5 \cdot 2$ \\
\hline
\end{tabular}

\section{Case Reports}

Case 1, a housewife aged 61 years, had had dysphagia for 6 months and progressive muscle weakness and rash for 2 months. There was an initial improvement on prednisone therapy, but she died 6 weeks after admission to hospital. At autopsy there were widespread metastases of an adenocarcinoma of uncertain origin (? ovary). The trunk and proximal limb muscles were wasted and their cut surfaces were of a pale orange colour; histologically there were focal degenerative changes in which the sarcoplasm had largely or completely disappeared and there was marked proliferation of sarcolemma cells, but there was no widespread loss of cross-striation or acute inflammatory process.

The test was performed before steroid therapy was started when the forearm was slightly oedematous. The mean duration of the hyaluronidase blebs was 2.8 minutes and that of the saline blebs $7 \cdot 8$ minutes.

Case 2, a man aged 57, gave a 4 months' history of rash, facial oedema, and muscle weakness and wasting; the "constant length phenomenon" could be demonstrated in many muscle groups. Electromyography revealed changes typical of myositis, and the urinary excretion of creatine was greatly increased.

The patient was receiving $15 \mathrm{mg}$. prednisolone daily at the time of the test. The skin of the forearm was warm, erythematous, and slightly scaly, thickened, indurated, and oedematous. The mean duration of the hyaluronidase blebs was 4.6 minutes and that of the saline blebs 73 minutes.

Nine patients aged from 26 to 42 years who satisfied the criteria of the American Rheumatism Association for a diagnosis of "definite" rheumatoid arthritis (Ropes, Bennett, Cobb, Jacox, and Jessar, 1956) were tested; five of them were males. The sheep cell agglutination test was performed on eight of them and was positive in five. The mobility of the skin was normal in all except one man aged 43 with familial anhidrosis, who had had rheumatoid arthritis for 6 years. The skin of his hands was dry, shiny, and atrophic, and there was some loss of skin mobility over the middle and distal phalanges and to a lesser degree over the left forearm where the test was performed. In this patient the mean duration of the saline blebs was $17 \cdot 5$ minutes and that of the hyaluronidase blebs $3 \cdot 2$ minutes, but in the group of rheumatoid patients as a whole the average durations (50.5 and 3.6 minutes respectively) did not differ significantly from those in the normal subjects.

23 male patients with "typical" ankylosing spondylitis (Sharp, 1957) ranging in age from 27 to 65 years (average 52) were studied. The sheep cell agglutination test was performed on sixteen of them and was negative in all. Only blebs containing hyaluronidase were investigated and their average duration (3.3 minutes) was shorter than normal $(p<0.05)$, a finding which may repay further investigation. West (1949) suggested that the symptom of "stiffness", which is usually a striking feature of the active stages of ankylosing spondylitis, may be due to a disturbance of the lubricant properties of the connective tissue ground substance, and that a defect of the metabolism of hyaluronic acid or related substances in the ground substance may play a part in the aetiology of the disease.

The group of patients with miscellaneous connective tissue diseases was composed as follows:

One had definite and another suspected disseminated lupus erythematosus.

One was suffering from hypopituitarism associated with rheumatoid arthritis.

One had Dupuytren's contractures and generalized thinness of the skin, but no evidence of hypopituitarism.

One had rheumatoid arthritis and scleroedema of the upper limbs.

Three had severe attacks of Raynaud's phenomenon with evidence of occlusion of digital arteries in two cases.

One, who had a polyarthritis with a subcutaneous elbow nodule and a positive sheep cell agglutination test, had severe Raynaud's attacks in the fingers with a normal reactive hyperaemia but with atrophy and sclerosis of the skin of the fingers and some loss of mobility of the skin of the distal forearms and face, but no rash. Muscle weakness had been a feature of relapses of the disease and the forearm muscles were firmer than normal and a "constant length phenomenon" could be demonstrated. 
One, who had a polyarthritis and a positive sheep cell test, had, in the earlier stages of the illness, had a rash on the trunk, extremities, and eyelids associated with profound muscle weakness. The rash and weakness subsided as the process remitted, but there was mild residual contracture in limb muscles. This phase of the illness closely resembled acute dermatomyositis but, during a subsequent relapse, the patient developed florid psoriasis with nail changes and absorption of the terminal phalanx of one finger and the rash and arthritis eventually passed into simultaneous remission.

In all these patients the rates of disappearance of the blebs did not differ significantly from normal.

Two patients had widespread connective tissue changes associated with visceral lesions and generalized oedema, but no definite diagnosis could be made.

One patient was suffering from hypopituitarism, rheumatic heart disease, and severe Dupuytren's contractures.

In these three the duration of the blebs both with and without hyaluronidase was shorter than normal.

One patient had rheumatoid arthritis with visceral lesions which had been preceded by severe myositis.

In this case the blebs containing hyaluronidase disappeared more rapidly than normal, but the duration of the saline blebs was normal.

Abnormal persistence of the hyaluronidase blebs was noted in two patients: one was an acromegalic and the other had severe Raynaud's attacks with atrophy and sclerosis of the skin of the digits and distal forearms without visceral involvement. The latter was thought to be suffering from a primary arteritis with secondary changes in the skin, but systemic sclerosis could not be excluded.

\section{Investigation of Factors concerned in the Disappearance of Blebs}

(a) Volume of Injection.-In systemic sclerosis there is usually increased resistance to the intradermal injection of fluid and increased extrusion of fluid along the needle track so that the abnormal duration of the blebs might be due to a diminished residual volume of injected solution. To investigate this possibility the test was performed using different volumes of injection in a normal subject and in two patients with well marked scleroderma, all at comparable skin temperatures (see (b) below). The results (Table IV) suggest that a diminished amount of fluid remaining at the injection site was unlikely to be a major cause of the prolonged duration of the blebs containing hyaluronidase observed in sclerodermatous patients. From animal experiments, Hechter (1947) concluded that, within wide limits, the volume of hyaluronidase solution injected intradermally had little influence on the time taken for $\stackrel{\bar{s}}{\rightarrow}$ the bleb to flatten out.

TABLE IV

EFFECT OF VOLUME OF INJECTION

\begin{tabular}{|c|c|c|c|c|c|}
\hline \multirow{2}{*}{\multicolumn{2}{|c|}{ Subject }} & \multirow{2}{*}{$\begin{array}{l}\text { Volume } \\
\text { (ml.) }\end{array}$} & \multicolumn{2}{|c|}{$\begin{array}{c}\text { Duration of Blebs } \\
\text { (min.) }\end{array}$} & \multirow{2}{*}{$\underset{\substack{\text { Skin } \\
\text { perature } \\
\left({ }^{\circ} \mathrm{C} .\right)}}{ }$} \\
\hline & & & $\begin{array}{c}\text { Hya- } \\
\text { luronidase }\end{array}$ & Saline & \\
\hline \multirow{3}{*}{ Normal } & & 0.03 & $4 \cdot 3$ & $77 \cdot 3$ & $32 \cdot 3$ \\
\hline & & 0.05 & $4 \cdot 3$ & $65 \cdot 8$ & $32 \cdot 2$ \\
\hline & & $0 \cdot 10$ & $3 \cdot 5$ & $73 \cdot 2$ & $32 \cdot 2$ \\
\hline \multirow{5}{*}{$\begin{array}{l}\text { Systemic } \\
\text { Sclerosis }\end{array}$} & \multirow{3}{*}{1} & 0.03 & $5 \cdot 4$ & $16 \cdot 0$ & $31 \cdot 8$ \\
\hline & & 0.05 & $6 \cdot 1$ & $35 \cdot 4$ & $30 \cdot 4$ \\
\hline & & $0 \cdot 10$ & $7 \cdot 3$ & $35 \cdot 8$ & $31 \cdot 4$ \\
\hline & \multirow{2}{*}{2} & 0.03 & $9 \cdot 4$ & $26 \cdot 6$ & $33 \cdot 1$ \\
\hline & & 0.05 & $7 \cdot 5$ & $24 \cdot 3$ & $32 \cdot 4$ \\
\hline
\end{tabular}

(b) Skin Temperature and Blood Flow.-Thickening of the intima of medium-sized and small arteriogs resulting in diffuse narrowing and occlusion of the lumen is a characteristic feature of the patholog of systemic sclerosis (Lewis, 1940; O'Leary, Montgomery, and Ragsdale, 1957; Rodnan, $\bar{\partial}$ Schreiner, and Black, 1957), so that it appeared 응

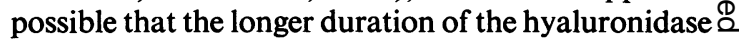
blebs in this condition might be the result of a reduc- $\vec{F}$ tion in the skin temperature from diminished blood 3 flow through the skin.

To investigate this possibility, the test was performed in three normal subjects at high and low skin temperatures induced by whole body heating and 0 cooling. In two of them the test was performed at $\frac{0}{3}$ high and low skin temperatures both with the cir-s culation intact and with the arterial circulation occluded by a cuff applied proximally to the limb. The results are shown in Table V (opposite). Occlu- $\frac{\text { O }}{J}$ sion of the arterial circulation appeared to have little effect on the rates of disappearance of the blebs but changes in skin temperature resulted in large altera- $N$ tions in the disappearance rates irrespective of the presence or absence of a free circulation, the rates being considerably showed by reduction in the skin $\omega$ temperature. The skin temperature had not been recorded in most of the patients with systemice sclerosis, but the available observations (Table VI, $\stackrel{\bar{D}}{\overparen{C}}$ opposite) suggested that it was unlikely that the? longer duration of the hyaluronidase blebs was due $T$ 
TABLE V

EFFECT OF SKIN TEMPERATURE AND CIRCULATION IN THREE NORMAL SUBJECTS

\begin{tabular}{|c|c|c|c|c|c|c|c|}
\hline \multirow{3}{*}{$\begin{array}{l}\text { Subject } \\
\text { No. }\end{array}$} & \multirow{2}{*}{\multicolumn{2}{|c|}{$\underset{\substack{\text { Skin } \\
\text { Temperature }}}{\left.{ }^{\circ} \mathrm{C} .\right)}$}} & \multicolumn{5}{|c|}{ Mean Duration of Blebs (min.) } \\
\hline & & & \multicolumn{2}{|c|}{ Circulation Intact } & \multicolumn{3}{|c|}{ Circulation Occluded } \\
\hline & $\begin{array}{c}\text { Range during } \\
\text { Test }\end{array}$ & Mean & Hyaluronidase & Saline & Hyaluronidase & Saline & $\begin{array}{c}\text { Duration of } \\
\text { Occlusion (min.)* }\end{array}$ \\
\hline \multirow{4}{*}{1} & $21 \cdot 2-23 \cdot 4$ & $22 \cdot 3$ & $7 \cdot 7$ & $74 \cdot 1$ & & & \\
\hline & $23 \cdot 0-25 \cdot 5$ & $24 \cdot 3$ & & & $7 \cdot 9$ & 91 & $\frac{20}{21 \cdot 5} \rightarrow$ off 2 \\
\hline & $32 \cdot 3-32 \cdot 8$ & $32 \cdot 6$ & $1 \cdot 5$ & $47 \cdot 3$ & & & \\
\hline & $33 \cdot 5-34 \cdot 6$ & $34 \cdot 1$ & & & $2 \cdot 3$ & $40 \cdot 5$ & $\frac{20}{19} \rightarrow$ off 2 \\
\hline \multirow{2}{*}{2} & $27 \cdot 8-24 \cdot 4$ & $26 \cdot 1$ & $5 \cdot 8$ & 42 & & & \\
\hline & $33 \cdot 1-34 \cdot 4$ & $33 \cdot 8$ & $2 \cdot 9$ & $29 \cdot 3$ & & & \\
\hline \multirow{6}{*}{3} & $22 \cdot 0-23 \cdot 5$ & $22 \cdot 8$ & $6 \cdot 0$ & $79 \cdot 5$ & & & \\
\hline & $23 \cdot 0-22 \cdot 8$ & $22 \cdot 9$ & & & $6 \cdot 2$ & $68 \cdot 3$ & 15 \\
\hline & $21 \cdot 5-25 \cdot 4$ & $23 \cdot 5$ & & & $4 \cdot 0$ & $49 \cdot 5$ & $\frac{20 \cdot 5}{17} \rightarrow$ off 2 \\
\hline & $34 \cdot 0-33 \cdot 0$ & $33 \cdot 5$ & $1 \cdot 0$ & $27 \cdot 0$ & & & \\
\hline & $33 \cdot 5-32 \cdot 0$ & $32 \cdot 8$ & & & $2 \cdot 5$ & $36 \cdot 5$ & $\frac{21}{13} \rightarrow$ off 2 \\
\hline & $33 \cdot 5-32 \cdot 3$ & $32 \cdot 9$ & & & $1 \cdot 1$ & $29 \cdot 0$ & 18 \\
\hline
\end{tabular}

* The circulation was occluded just before the injections were made and the blebs containing hyaluronidase were followed to disappearance during the period of occlusion.

TABLE VI

DURATION OF BLEBS IN SIX PATIENTS WITH SYSTEMIC SCLEROSIS IN WHOM SKIN TEMPERATURE WAS RECORDED

\begin{tabular}{|c|c|c|c|c|c|}
\hline \multirow{2}{*}{$\begin{array}{l}\text { Patient } \\
\text { No. }\end{array}$} & \multirow{2}{*}{$\begin{array}{c}\text { Age } \\
\text { (yrs) }\end{array}$} & \multirow{2}{*}{$\begin{array}{c}\text { Duration of } \\
\text { Symptoms } \\
\text { (yrs) }\end{array}$} & \multirow{2}{*}{$\begin{array}{l}\text { Skin Tem- } \\
\text { perature } \\
\left.\text { ( }{ }^{\circ} \mathrm{C} .\right)\end{array}$} & \multicolumn{2}{|c|}{$\begin{array}{c}\text { Duration of Blebs } \\
\text { (min.) }\end{array}$} \\
\hline & & & & $\begin{array}{l}\text { Hya- } \\
\text { luronidase }\end{array}$ & Saline \\
\hline $\begin{array}{l}1 \\
2 \\
3 \\
4 \\
5 \\
6\end{array}$ & $\begin{array}{l}14 \\
17 \\
17 \\
21 \\
37 \\
47\end{array}$ & $\begin{array}{l}1 \cdot 7 \\
9 \cdot 0 \\
3.0 \\
2 \cdot 5 \\
3 \cdot 3 \\
5 \cdot 0\end{array}$ & $\begin{array}{l}34 \cdot 0 \\
30 \cdot 3 \\
30 \cdot 0 \\
30 \cdot 4 \\
32 \cdot 4 \\
30 \cdot 5\end{array}$ & $\begin{array}{l}3 \cdot 5 \\
6 \cdot 6 \\
8 \cdot 6 \\
6 \cdot 1 \\
7 \cdot 5 \\
8 \cdot 5\end{array}$ & $\begin{array}{l}21 \cdot 9 \\
37 \cdot 0 \\
31 \cdot 8 \\
35 \cdot 4 \\
24 \cdot 2 \\
43.6\end{array}$ \\
\hline
\end{tabular}

to a reduced skin temperature in the sclerodermatous patients.

(c) Clearance of Radioactive Sodium. - The results of an experiment in a normal subject in which the injections contained radioactive sodium are shown in Fig. 2 (overleaf). The rate of disappearance of the radioactive sodium from the injection site and its immediate vicinity was slightly increased by the hyaluronidase, the half-clearance time of the radioactive sodium being $7 \cdot 1$ minutes without and 5.6 minutes with hyaluronidase. Repetition of this experiment in the same subject on a different occasion gave half-clearance times of $5 \cdot 8$ and $5 \cdot 1$ minutes respectively. When the disappearance of radioactive sodium from the centres of the blebs was investigated in this subject by counting the radiation through a circular aperture $4 \mathrm{~mm}$. in diameter placed over the centre of the bleb, the halfclearance times were 4.5 minutes without and 3.5 minutes with hyaluronidase. Thus, in each case, the rate of disappearance of the radioactive sodium was slightly accelerated by the hyaluronidase, but in this respect its effect was much less than its effect in increasing the rate of disappearance of the palpable bleb. Barron, Veall, and Arnott (1951) could find no correlation between the rate of clearance of radioactive sodium after intradermal saline injections in tubed skin pedicles and the persistence time of the blebs. Occlusion of the arterial circulation (Fig. 3, overleaf) caused cessation of sodium clearance from the centre of the bleb in the case of saline injections, and there was barely detectable clearance from the bleb containing hyaluronidase. 


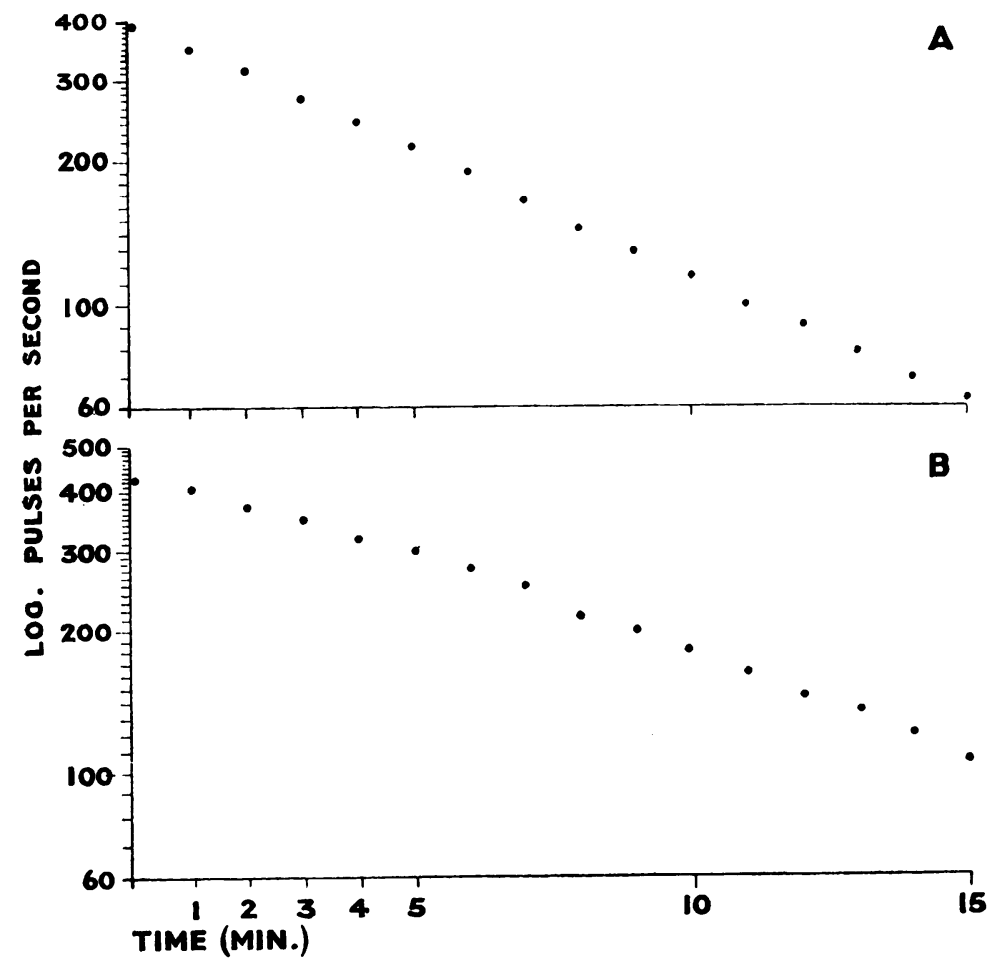

Fig. 2.-Clearance of radioactive sodium from blebs and immediately surrounding area (A) with and (B) without hyaluronidase in a normal subject.

Acceleration of the rate of disappearance of the blebs by hyaluronidase might be an- $\frac{0}{\omega}$

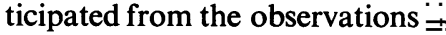
of Day (1952) and from the known in vitro effect of the enzyme in decreasing the 흘 viscosity of solutions of muco- $\frac{\bar{m}}{\bar{D}}$ polysaccharides of the connec- $\stackrel{\mathbb{Q}}{\stackrel{2}{\Omega}}$ tive tissue ground substance. Day showed that the rate of $\vec{\circ}$ flow of saline through a mem-. brane of mouse connective $\overrightarrow{\vec{\omega}}$ tissue was increased ten to $\circ$ twenty times by hyaluronidase. He suggested that the ground substance of connective tissue

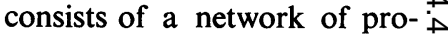
tein fibrils "waterproofed" by $\vec{\sigma}$ impregnation with molecules 웅

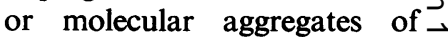
hyaluronic acid, and that the 0 effect of hyaluronidase in in- $\mathbb{\Phi}^{\circ}$ creasing permeability of the $\frac{\Phi}{3}$ tissue was due to removal of $\underset{\mathbb{D}}{0}$ these molecules and the opening up of spaces through of which the saline could flo The results of the experimeris in which radioactive sodium was employed suggest, how-

\section{Discussion}

On raising an intradermal bleb by injection of an isotonic solution, the tensile elements in the skin are stretched and the elastic recoil of these structures is presumably the force responsible for flattening out the bleb. The rate at which this occurs will depend on the balance between this force and the forces resisting the restoration of the normal skin contour, namely the frictional resistance to flow of the injected solution provided by the macro molecules of the ground substance and the fibrous elements of the dermal connective tissue (Fessler, 1957), and the viscosity of the ground substance preventing flattening and "sinking in" of the bleb which might occur with relatively little flow of the solution from the injection site.

The force required to make an intradermal injection and the amount of injected fluid extruded along the path of the needle are usually greater in sclerodermatous than in normal skin. This suggests that the more rapid disappearance of the saline blebs observed in the patients with systemic sclerosis may in part be due to an increased elastic resistance to deformation of sclerodermatous skin. ever, that the main effect of hyaluronidase may be to decrease the viscosity of the ground substance and $\stackrel{\circ}{\circ}$ thus allow the bleb to flatten out with relatively $\overrightarrow{\vec{P}}$ little flow of the injected solution away from the $\frac{3}{3}$ site of injection. It was found that arrest of the blood flow through the skin resulted in cessation of sodium clearance, but, in other experiments, arrest of the blood flow was found to have no effect on the rates of disappearance of the blebs. Moreover, the rates of disappearance of sodium from the injection sites bore no direct relationship to the rates of disappearance of the palpable blebs either with or $₹$ without hyaluronidase, so that the more rapid $\frac{0}{5}$ restitution of the normal skin contour with hya- $\rightarrow$ luronidase must have occurred with relatively little transport of sodium from the vicinity of the injection $\bar{N}$ site, and it is unlikely that any substantial transport $\sigma$ of water of the injected saline could occur without $\tilde{O}$ movement of the sodium. A decrease in the viscous $\underset{\omega}{\mathrm{\omega}}$ resistance of the tissue might be expected to allow the volume of fluid contained in the palpable part 0

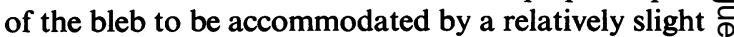
lateral spread and possibly some "sinking in" of $\stackrel{\mathcal{P}}{+}$ the bleb. 


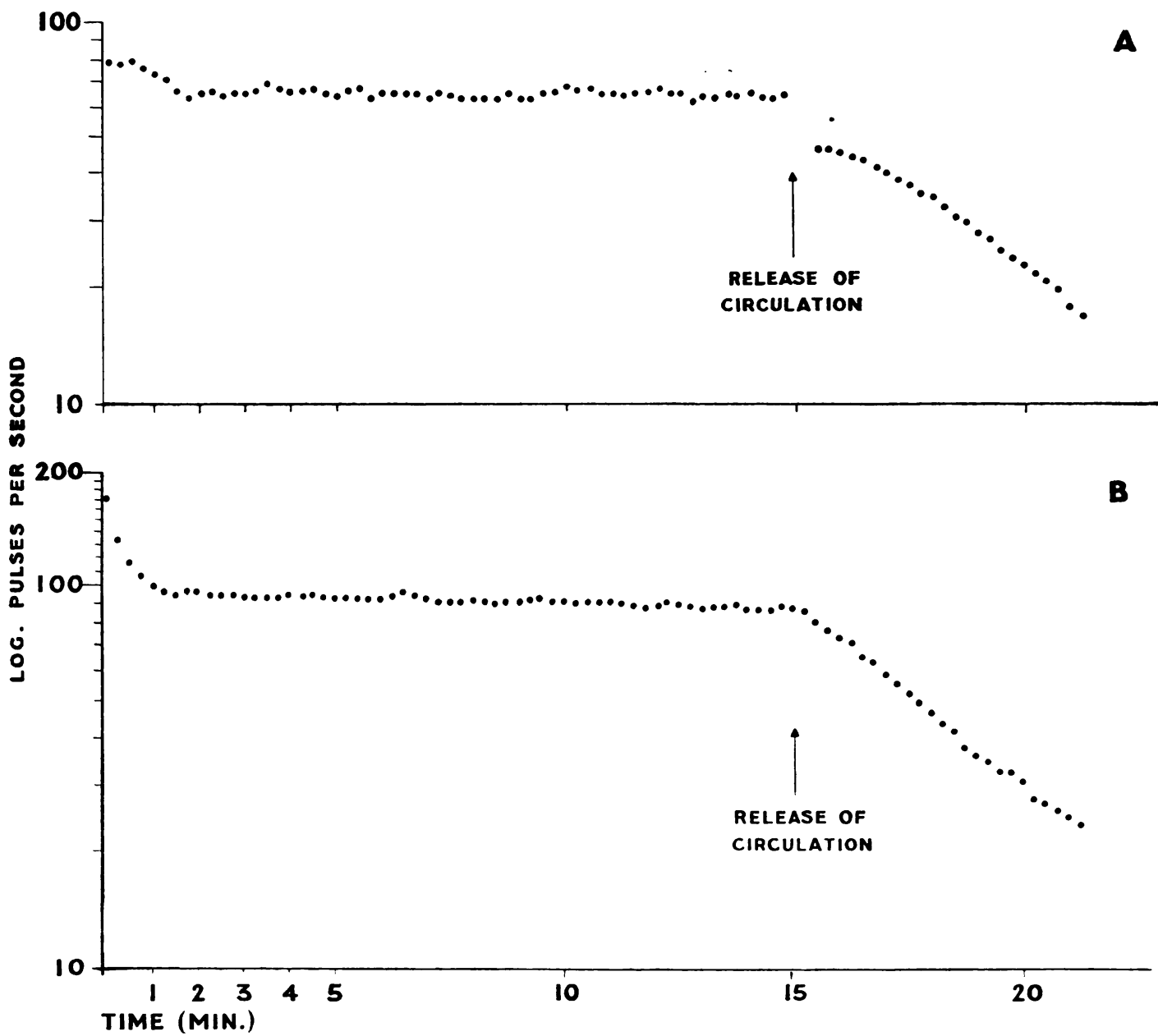

Fig. 3.-Effect of occlusion of arterial circulation on clearance of radioactive sodium from centre of blebs (A) with and (B) without hyaluronidase in a normal subject.

The most probable explanation of the delay in disappearance of the blebs containing hyaluronidase in sclerodermatous skin would appear to be that there is in this condition either a quantitative reduction of the mucopolysaccharides of the ground substance or a qualitative change rendering them insusceptible or inaccessible to the enzyme. Preliminary results of electron-microscopic studies (Chapman and Peach, unpublished data) suggest that the amorphous material surrounding the collagenous fibres in the deeper layers of the dermis is reduced in quantity. The hyaluronic acid of normal synovial fluid is thought to function as a lubricant of the joint surfaces (Gardner, 1950), and it is possible that the mucopolysaccharides of connective tissue may play a similar role in facilitating movements between its constituent fibres. Loss of mobility in the skin and gastro-intestinal tract is a striking clinical feature of systemic sclerosis, and a characteristic silky "squeaking" crepitus can frequently be felt on movement of joints, tendons, and bursae at many sites; in one case observed post mortem there was increased frictional resistance when the finger was passed over the surfaces of these structures. The abnormality of the ground substance in systemic sclerosis may not therefore be 
confined to affected skin, but may be a feature of the connective tissue disorder in other affected structures.

\section{Summary}

The duration of the palpable blebs produced by the intradermal injection of physiological saline with and without added testicular hyaluronidase was observed in normal subjects and in patients with systemic sclerosis, dermatomyositis, rheumatoid arthritis, ankylosing spondylitis, or other connective tissue diseases.

In normal subjects the rate of disappearance of the blebs was greatly accelerated by the addition of hyaluronidase. The rate of disappearance was accelerated by raising the skin temperature and retarded by lowering it, but was little affected by variations in the volume of injection (between 0.03 and $0.1 \mathrm{ml}$.) or by cutting off the skin circulation. The clearance of radioactive sodium from the injection sites was only slightly accelerated by hyaluronidase. When the skin circulation was occluded, the clearance of sodium from the centre of a saline bleb ceased and there was only a barely detectable clearance when the bleb contained hyaluronidase.

In patients with systemic sclerosis, the blebs containing hyaluronidase usually persisted longer and the saline blebs disappeared more rapidly than in normal subjects; the hyaluronidase appeared to be less effective in those with less advanced skin changes. In almost all patients with diseases other than systemic sclerosis, the addition of hyaluronidase resulted in a normal or increased acceleration of the rate of disappearance of the blebs.

The findings suggest that, in systemic sclerosis, there is either a reduction in the amount or a qualitative abnormality of the ground substance of the dermal connective tissue.

We are greatly indebted to Prof. J. H. Kellgren for useful advice and discussion, to Dr. J. Ball, who carried out the sheep cell agglutination tests, and to Miss Freda Bier for assistance with the statistical tests. Drs. S. K. Bannerjee, E. W. Emery, and R. Harris gave much advice and assistance in the radioactive sodium studies.

\section{REFERENCES}

Ball, J. (1950). Lancet, 2, 520.

Barron, J. N., Veall, N., and Arnott, D. G. (1951). Brit. J. plast. Surg., 4, 16.

Chain, E., and Duthie, E. S. (1939). Nature (Lond.), 144, 977.

Chain, E., and Duthie, E. S. (1939). Nature

Chapman, J. A., and Peach, R. Unt., Unublished observations.

Day, T. D. (1952). J. Physiol. (Lond.), $117,1$.

Duran-Reynals, F. (1942). Bact. Rev., 6, 197.

Fessler, J. H. (1957). Nature (Lond.), 179, 426.

Gardner, E. (1950). Physiol. Rev., 30, 127.

Hechter, O. (1947). J. exp. Med., 85, 77.

Holborow, E. J., and Keech, M. K. (1951). Brit. med. J., 2, 1173.
Kellgren, J. H., Ball, J., and Tutton, G. K. (1952). Quart. J. Med 21, 405 .

Lewis, T. (1940). Brit. J. Dermatol., 52, 233.

O'Leary, P. A. Montgomery, H., and Ragsdale, W. E. (1957? A.M.A. Arch. Dermatol., 75, 78 .

Rodnan, G. P., Schreiner, G. E., and Black, R. L. (1957). Amei: J. Med., 23, 445.

Ropes, M. W., Bennett, G. A., Cobb, S., Jacox, R., and Jessar, R. (1956). Bull. rheum. Dis., 7, 121.

Seifter, J., Baeder, D. H., and Dervinis, A. (1949). Proc. Soc. exp Biol. (N.Y.), $72,136$.

Sharp, J. (1957). Brit. med. J., 1, 975.
Shuman, C. R., and Finestone, A. J. (1950). Proc. Soc. exp. Bio $(N . Y), 73,$.248 .

West, H. F. (1949). Ann. rheum. Dis., 8, 143.

Barriére cutanée dans la sclérose généralisée et dans d'autres maladies rhumatismales

RÉSUMÉ

On étudia la durée des bulles palpables provoquées pa l'injection intradermique d'eau physiologique, avec oü sans hyaluronidase testiculaire, chez des sujets normaux et chez des malades atteints de sclérose généraliséế dermatomyosite, arthrite rhumatismale, spondylarthrite ankylosante et autres maladies du tissu conjonctif.

Chez des sujets normaux, l'adjonction d'hyaluronidase faisait disparaître les bulles plus rapidement. Cette disparition était accélérée par l'augmentation de la température cutanée et ralentie pas sa diminution, maif était peu influencée par le volume injecté (entro 0,03 et 0,1 c.c.) ou par l'interruption de la circulation cutanée. L'élimination du sodium radioactif de l'endro de l'injection était à peine accélérée par l'hyaluronidase L'occlusion de la circulation cutanée arrêtait l'élimiłation du sodium du centre de la bulle d'eau physig్fo gique; avec l'hyaluronidase il n'y avait qu'une ébaushę d'élimination.

Chez des malades atteints de sclérose généralisée, bulles à l'hyaluronidase persistaient généralement plus longtemps et les bulles à l'eau physiologique disparais saient plus rapidement que chez des sujets normauxo l'hyaluronidase paraissait moins efficace quand la maladio de la peau était peu avancée. Chez presque tous les malades souffrant de maladies autres que la scléros généralisée, l'adjonction d'hyaluronidase faisa disparaître les bulles à une vitesse normale ou accélérée.

Ces résultats suggèrent que, dans la sclérose généralisée la substance de fond de tissu conjonctif de la peau est. soit réduite quantitativement soit altérée qualitativementw

Barrera cutánea en la esclerosis generalizada y en otras enfermedades reumáticas

\section{Sumario}

Se estudió la duración de las ampollas palpables provocadas por inyecciones de suero artificial, con o sin añadidura de hialuronidasa testicular, en sujetos no males y en enfermos con esclerosis generalizada, dermatomiositis, artritis reumatoide, espondilartritis anquilof sante y otras enfermedades del tejido conjuntivo.

En los sujetos normales, las ampollas desaparecíaf rapidamente en presencia de hialuronidasa. Esta desaparición era accelerada por una aumentación de lig temperatura de la piel y retrasada por su disminución pero el volumen inyectado (entre 0,03 y 0,1 c.c.) o lo interrupción de la circulación cutánea no tuvieron efect\& alguno sobre la duración de las ampollas. La eliminá ción del sodio radioactivo del sitio de inyección fué pocó accelerada por la hialuronidasa. La oclusión de lic 
circulación cutánea paró la eliminación de sodio del centro de la ampolla con el suero artificial; con hialuronidasa la eliminación fué poquísima.

En los enfermos con esclerosis generalizada, las ampollas con hialuronidasa persistían generalmente más tiempo y las ampollas con suero artificial desaparecían más rapidamente que en los sujetos normales; la hialuronidasa parecía ser menos eficaz en pieles con enfer- medad poco adelantada. En casi todos los sujetos con enfermedades otras que la esclerosis generalizada, la hialuronidasa hacía desaparecer las ampollas con una velocidad normal o mayor.

Estos resultados sugieren que, en la esclerosis generalizada, la substancia de fondo del tejido conjuntivo de la piel está reducida cuantitativa o alterada cualitativamente. 